\title{
The Ethics of Development-induced Displacement
}

\author{
Peter Penz
}

\begin{abstract}
This concluding piece on the ethics of development-induced displacement notes how all of the preceding articles find the displacement of people by development policies and projects morally objectionable and that it should be prevented. The question of why it is morally objectionable, how states attempt to justify it nevertheless, and how acceptable such justifications are, is addressed in some detail. This is a discussion that falls into the terrain of the new field of development ethics. Development's promise to reduce poverty and inequality have been used to justify large projects and disruptive policies. In assessing these justifications, three lines of ethical argument are explored, one in terms of the public interest, a second in terms of self-determination, and third in terms of distributive justice. The conclusion is that, while forced migration cannot be categorically declared unjustifiable, the conditions that must be met for its justifiability are considerable.
\end{abstract}

\section{Précis}

Ce texte conclusif sur l'éthique du déplacement de populations du au développement fait d'abord observer combien toutes les contributions du présent numéro considèrent que le déplacement de populations causé par des politiques de développement est moralement condamnableet se doit d'être évité. La question du pourquoi de ce caractère moralement condamnable, la description des tentatives des gouvernements pour le justifier malgré tout, et la question du degré d'acceptabilité de telles justifications sont abordés ici en détails. La présente discussion s'inscrit dans le domaine nouveau del'Éthique du Développement. La promesse que fait le déve-

Peter Penz is Associate Professor, Faculty of Environmental Studies, York University, Toronto. loppement de réduire la pauvreté et les inégalités a été utilisée pour légitimer des projets pharaoniques et des politiques déstabilisatrices. En évaluant de telles procédures de justification, on exploite ici trois types d'arguments éthiques. Le premier se formule en termes d'intérêt public, le second en termes d'auto-détermination, le troisième en termes de justice distributive. La conclusion est que la migration forcée ne peut être déclarée injustifiable de façon absolument catégorique, mais que les conditions devant être rencontrées pour que sa légitimité se fasse jour sont d'une complexité considérable.

\section{Displacement and Development Ethics}

The implication of the preceding articles is that the displacement of people by development policies and projects is morally objectionable and that it should be prevented. In this short article I will address the question of why it is morally objectionable, how states attempt to justify it nevertheless, and how acceptable such justifications are. It falls into the terrain of the new field of development ethics. ${ }^{1}$

But first a prior question: why engage in complex ethical analysis of an issue such as development-induced displacement in the first place? This question arises from two diametrically opposed orientations. One argues that economic advancement has always meant that the landscape of production and distribution is changed and people are often forced to move as a result. It is claimed that people need to learn to adjust (and, perhaps, that they be helped to adjust). Displacement has been ubiquitous in industrial development, whether capitalist or socialist. In fact, it reflects mobility and as such is the opposite to immobility, being trapped in a particular place. Mobility is desirable, immobility is not. The former indicates freedom, the latter its lack. In any case, as long as development serves the public interest, there is no larger ethical issue involved. This position represents a form of developmentalism that is morally simplistic in that it treats only the ends of development as involving moral judgments, but not the means. It will be addressed further under the publicinterest argument below. The other orientation that would short-circuit an ethical analysis is the opposite to the first. It is no less simplistic morally. According to this perspective, displacement is ethically unacceptable, pure and simple, and so are any development projects and policies that lead to it. But this line of argument second ignores the justifications that can and have been offered for development-induced displacement. Simplistic moralism, whether pro- or anti-development, is objectionable. Both the means of development and their justifications require ethical scrutiny.

\section{Displacement as Evil}

The initial moral significance of displacement resides in its very definition. To displace people means to force them to leave their home, village, town, region or country. To the extent that coercion is morally objectionable, displacement is too. Moreover, displacing people usually involves harming them. They lose their land, their livelihoods, their social networks and the cultural patterns contained in them, the environment for which they have accumulated experience and knowledge and to which they are attached, to mention just the most basic losses. Thus, apart from the moral objection to coercion, there is the further objection to harming people in ways other than contravening their wishes and commitments. Whether various kinds of compensation (including assistance with becoming reestablished 
in a suitable alternative location) can offset the harm then becomes a crucial question.

Migration forced by development places responsibility on the shoulders of those taking the development initiatives. If development is an unguided process, one driven by a national or global system that is beyond the control of any identifiable human agency, then of course there is no such responsibility. However, choices with respect to development are made. The economy is not an impersonal machine. While there may be structural constraints on decision-makers, they still have choices such as whether to protect the land rights of forest-dwellers in the face of logging interests or whether to support a system of many small dams that have limited displacement as opposed to one of a few big dams with extensive displacement.

Given that there is moral responsibility for development decisions with displacement effects, this in itself does not mean that development choices that dislocate people are necessarily immoral. Even if it is recognized that displacement is bad because it involves harm or coercion, it is possible that it is a justifiable evil when considered within the larger picture. In particular, the question arises of whether the good that development does can morally outweigh its bad consequences, including uprooting people.

My brief exploration of this question will involve three stages. I will consider, in turn, arguments in terms of the public interest, liberty, property rights, and community autonomy, and equal sharing. ${ }^{2}$ My conclusion will be that, while not all displacement due to development can be ruled out as morally unjustifiable, such justification and the social provisions that satisfy it have to go beyond the public interest and compensation for losses.

\section{The Public Interest}

Much economic development is justified in terms of the public interest. From this public-interest perspective, as long as the overall well-being of people is increased, even development projects that have the unfortunate effect of uprooting some people should be pursued (unless there are alternative projects that would provide even higher net benefits, in which case these should be adopted instead). This moral stance is in fact operationalized in costbenefit analysis, which is the standard method of evaluating development projects. To be satisfactory on its own terms, this approach must include displacement effects as costs. These include the loss of land, homes, fields, and transportation and other infrastructure that may be involved, the disruption of livelihoods and communities, the separation from culturally significant places, and the cost for people to reestablish themselves elsewhere. Cost-benefit analysis is supposed to convert all this into a single dimension of commensurability, specifically money. Theoretically, this is to be done by people's individual valuation in money terms. Thus the losses involved in leaving a community are to be evaluated by determining what individuals would need in terms of compensation in order to accept leaving the community. Of course, implicit in this assessment are the alternatives available to them. The thrust of this approach is that all costs and benefits are to be taken into account in determining the overall net benefits of a project or policy. It will be in the public interest if it generates net benefits and if there is no alternative option with higher net benefits. ${ }^{3}$

There are several problems with this approach:

(a) The concept of the public interest may be employed to subordinate the interests of people to some alleged larger good, such as the interests of the state, or to subordinate people's own notions of their interests to some attributed ideal notion.

(b) Even when the public interest is conceived as the aggregate of the interests of the people as individuals, it is prone to being subverted by the actual practice of development.

(c) Most crucial for this discussion is that the idea of the public interest neglects distributive considerations.

(a) The notion of the public interest lends itself to very different interpretations. Some conceptions subordinate the interests of people to some larger good. Instead of consisting of the aggregate of interests of the population, the public interest may be deemed to be the well-being of some overarching entity. For example, the unity and security of the state may be treated as the most basic aim. Thus, in Indonesia and Bangladesh tribal peoples in frontier areas (e.g., Western New Guinea and the Chittagong Hill Tracts, respectively) have been viewed with suspicion and development has been brought to these areas partly as a way of settling loyal populations from the national heartland there. This led to extensive suffering as well as conflict. Especially as customary land occupancy often lacked legal backing, conflicts over land led to violent confrontation and large-scale displacement due to development-induced conflict, with subsequent large-scale deaths and refugee flows (Penz 1993). Even if the public interest consists of the interests of people, it may be conceived without reference to their own notion of what is in their best interest. The public interest may be regarded as the "development" of people in a particular direction, such as becoming "civilized". Thus, even post-colonial states have pursued the development of marginal groups out of their "backwardness" as something desirable in itself (Bodley 1990, ch. 8). Such moral paternalism smacks of old-style colonialism and is objectionable in that it denies moral agency to such marginal groups.

(b) Even when the public interest is clearly recognized as consisting of the interests of people, much development violates it in practice. The politics of development are crucial here. Development is often little more than a struggle between various sections of the national elite over economic opportunities. In some cases there is not so much an extractive struggle as a systematically organized regime of ex- 
ploitation; thus Philip Howard referred in his article to a kleptocratic regime (rule by thieves) in Haiti under the Duvaliers. In either case, what is involved is the self-interested use of power. A dam, an irrigation project or a tree plantation may not serve the public interest at all, regardless of how the public interest may be conceptualized, but merely sectional interests. Or it is chosen because it contributes to state revenues rather than in accordance with any reasonably comprehensive conception of the public interest. Even if there is a commitment to a public interest approach, development politics mean that certain interests have greater political recognition than others. Forest-dwellers and other marginal groups are likely to be rather invisible politically and to have their interests ignored in any public-interest assessment. Moreover, even in a systematic cost-benefit analysis, some things are difficult to quantify, and such difficulties are liable to lead to their neglect. Anything not somehow obtained, with reasonable ease, from market prices, which the theory takes to reflect individual valuations, involves such difficulties. For that reason, social, cultural and environmental losses are prone to neglect. In general to claim that all development serves the public interest would be a heroic assumption, to say the least.

(c) Most striking is the neglect of distributive considerations in a pure public-interest perspective. It is only overall net benefits that determine the public interest, not how these are distributed. It is thus possible to approve of a project in the name of the public interest, even though many people are harmed, as long as this harm is outweighed by the gains to the country. Yet it stands in violation of any reasonable notion of social justice. One position is that all those affected should not only have all their losses assessed, as part of a public-interest calculation of aggregate net benefits, but should be compensated for them, so that they are not harmed by the development action. The entitlement to compensation and, more fundamentally, the entitle- ment to consent to development impacts, including displacement, and to refuse such consent is the focus of the next perspective.

\section{Freedom, Property, and Self- Determination}

According to the libertarian perspective, what makes displacement objectionable is the violation of freedom that is involved. Freedom and the right to property without interference that goes with it are the central values of this perspective. The legitimate basis of change is exchange, so that the only moral way that a dam can be built for a reservoir in a populated valley is to have the valley inhabitants accept offers of remuneration or other forms of compensation (e.g., land or employment elsewhere). No one can be forced out without violating the central moral principle of liberty.

Although libertarianism articulates the principle of liberty strictly in reference to individuals, a communal or "communitarian" version of it is possible as well. In this case, it is communities that have the fundamental right to be self-determining and to be free from coercion from the outside. While within communities public-interest actions may be taken, the public-interest morality does not apply to relations with other communities, the country or the world as a whole. (Part of the rationale for this position may be that only communities are sources of values and thus cannot be subordinated to any supervening value system.)

Whether in relation to individuals or to communities, particular violations of self-determination can be justified only if it is to prevent other, more serious violations, such as by an invading outside force. In general, it means that displacement as forced migration is immoral; only negotiated voluntary migration is justifiable.

This position, especially in its communal form, has much to be said for it. In practical terms, it means that development projects have to be negotiated with the affected communities. In fact, development becomes much more community-governed under this self- determination perspective. The latter requires a fundamental reorientation from the current top-down and business-privileging approach to development.

Nevertheless, this position is problematic. Persuasive critiques come both from the public-interest perspective and from the equal-sharing perspective that we still have to consider. From the public-interest perspective, the first point to be made is that the conception of self-determination or liberty employed is a particular and very limited one. Specifically, it is a negative conception in that it is concerned with freedom from interference by others, rather than the freedom and capacity to choose and pursue certain options. The latter is a positive conception of self-determination or liberty. This raises public-interest considerations in that the lack of development can be seen to constitute a lack of positive self-determination. Individuals and communities cannot do certain things because of their poverty, limited resources or restricted technologies or skills. Thus, building dams to irrigate fields and provide electricity to villages and rural industries may enhance self-determination in improving the range of options available to people and communities. In that case, the negative self-determination not to be displaced may stand in tension with the positive self-determination of expanding the range of activities that become possible. This then becomes a similar trade-off as that involved in cost-benefit analysis.

A second criticism of the self-determination perspective that comes from the public-interest perspective is a very practical one. Individuals (and even communities) may refuse to accept even a very generous offer to move, not because it would not make them better off than before, but simply because, by holding out for extravagant compensation, they can enrich themselves at the expense of the project funders, which may be taxpayers. This presumably is a major reason for the power of eminent domain that states tend to retain for themselves. To 
be fair, such coercive authority needs to be coupled with fair compensation, but the compensation may need to be determined by an independent adjudicator rather than the person or family, because of this opportunity for exploitation of public-interest projects.

From an equal-sharing perspective, the problem is that the very strong protection that libertarianism and analogous communitarianism accord to individuals and communities, respectively, also serves the privileged. With such protection, land redistribution from the big landowners to land tenants or labourers would not be possible. 4 More specifically regarding displacement, self-determination as such has nothing to say about how the benefits from development projects should be shared. One plausible position is to say that those evicted should not only be fully compensated, but that they should receive a generous share of the development benefits of the project for which they had to make way. But such considerations of distributive justice lead us into the next perspective.

\section{Inequalities and Justice}

An equal-sharing perspective broadens the question from simply the treatment of those displaced or otherwise harmed to the overall effects, in a manner similar to that of the public-interest perspective. However, instead of focusing on the total of net benefits, the focus is on the distribution of costs and benefits. In fact, it broadens it even further because the pre-existing inequalities are brought into the picture.

An equal-sharing orientation can have different sources in ethical theories. One is that equal sharing is the fundamental moral default option. Since everyone is entitled to equal consideration, the burden of proof falls on those who want to argue for a distributive solution other than equality. Two arguments that are widely offered are those of incentives and those of property rights. The incentives argument is a kind of public-interest argument in that individuals are to be rewarded for contributing to the public interest. But it raises questions of what constitutes the public interest as well as distributive justice within this public interest. In other words, distributive justice enters into the justification of incentives. One kind of incentive argument (which comes from John Rawls's [1971] contractarianism) is that incentives should be structured so as to improve the living conditions of the most disadvantaged. Inequalities in that case are justified only by benefiting the poor, e.g. by offering health workers higher rewards for locating in rural communities or by rewarding engineers that develop low-technology innovations. It is a justification of inequalities, but a very constrained one. In general, it works in the direction of reducing inequalities, including by providing incentives to those assisting the poor to improve their conditions.

The other argument against equality is that of the priority of property rights. While the existence of property rights makes life predictable in an important way, creates a sphere of selfdetermination and also constitutes an incentive to productivity, they cannot be treated as morally absolute. Much property has been inherited, raising questions of moral entitlement to inheritance as well as questions about the legitimate holding of the property by ancestors. In fact, the pervasiveness of injustice in the historical acquisition and transfer of property (with little land, for example, being free from conquest, force and fraud at some point in the historical chain of transfers) makes property rights at most a morally contingent right. To the extent that inherited inequalities undermine equality of opportunity, their moral basis is very much in doubt.

If ethical development is to serve not only the public interest, but also distributive justice in the form of equality of opportunity (in more than a superficial sense), then development-induced displacement must be considered in a broader context. If development initiatives serve to reduce inequalities, for example by providing electricity and irrigation to the poor and inundating the plantations and mansions of the rich, then displacement may not be unjust in the same way as it is when it displaces those who are already disadvantaged. There may be an important question of fairness among the rich (those affected and those not), i.e. "horizontal" as opposed to "vertical" equity, but, as long as this can be sorted out by appropriate transfers among the rich, distributive justice is served rather than violated. Displacement should still be minimized as a matter of the public interest or to minimize coercion or the required rectification of horizontal inequities, but it should not stop development that makes the distribution more just.

It becomes trickier when the beneficiaries are one group of disadvantaged, e.g. peasants, and the displaced are another group of disadvantaged, e.g. forest-dwellers. In that case, horizontal equity among the disadvantaged becomes crucial. It would certainly be unjust to benefit the peasants because they are part of mainstream society, while uprooting indigenous forest-dwellers who practice a tribal way of life. Not only does distributive justice require that anyone displaced is fully compensated, but that those displaced receive a fair share of the benefits of the development. This is an important point. Development projects that fully compensate those dislocated or otherwise harmed may still violate distributive justice if the benefits are unfairly distributed. It is true that particular development projects are designed to improve the conditions of particular groups so that it may be impossible for a particular project to meet this criterion; but the requirement of the just distribution of benefits can be applied to the overall pattern of development.

\section{Indirect Displacement and Just Development}

The discussion so far is most applicable to direct displacement resulting from development. It is then reasonably clear who the displacement victims are and who ought to receive compensation and share in the development benefits. In the case of indirect 
displacement, there is no such clarity. When a poor peasant family sells its little plot of land and switches to making a living with insecure day-labour employment, it is not necessarily clear whether this was a result of deliberate development initiatives or a result of processes of economic change beyond the control of development authorities. In such cases, however, it is not inappropriate to treat development in general as a national project, which has its victims, and these victims are then entitled to compensation and a share in the development benefits. But compensation is difficult to determine in such cases and a share in the development benefits is a loose notion at best. What this point, and the preceding one concerning the difficulty of fairly distributing the benefits of particular projects, mean is that those who are left ormade poor in the development process and thus prone to displacement are entitled to assistance. A bottom-up approach to development mentioned in the introductory overview to this edition of Refuge would in fact do this.

\section{Conclusion}

The self-determination perspective is important in requiring consultation with communities in the design of development projects that will impact them significantly. It requires that the communities' own conception of their interests and their management of their environment be respected. More specifically, it requires that forced migration be avoided and replaced by negotiated resettlement terms, wherever the need for population movements cannot be avoided. But self-determination cannot be asserted in such unqualified terms that development which serves both the public interest and distributive justice is blocked. There are conditions under which development-induced displacement can be justified. But these are strong conditions, including that coercive displacement is as much as possible avoided by negotiated resettlement, is quantitatively minimized, and is fully compensated. Full compensation means recognizing the full range of losses that those dislocated experience. Moreover, the justifying conditions include that the development benefits contribute to reducing poverty and inequality. These conditions have been massively violated not only in the particular displacement processes which have been described in this edition of Refuge, but typically also in the globally ubiquitous pattern of development-induced displacement.

\section{Notes}

1. This field is represented by the International Development Ethics Association. Inquiries concerning this organization can be directed to Prof. David A. Crocker, Institute for Philosophy and Public Policy, 3111 Van Munching Bldg., University of Maryland, College Park, MD 20742, USA.

Email: dcrocker@puafmail.umd.edu

2. This classification is a slight elaboration of the very basic framework I employed in Penz 1997, which confined itself to the no-harm and equal-sharing perspectives in the treatment of international environmental justice. The one employed in this article roughly corresponds to three of the perspectives on social justice in standard classifications in political philosophy, namely utilitarianism, libertarianism and egalitarianism. Another perspective, that of contractarianism, is an amalgam of these three. Communitarianism can take a variety of forms; I will discuss one form in connection with libertarianism. For such classifications and explanations of the perspectives contained in them see e.g. Smith 1984, chapters 4 and 5; and Sterba 1992. For a more elaborate classification specifically of perspectives in development ethics, see Penz 1991.

3. There is a problem in cost-benefit analysis in that valuations by individuals are determined by their wealth levels, but this is more of a distributive issue of concern to the equal-sharing perspective introduced below than to the public-interest perspective. For a fuller discussion of cost-benefit analysis from an ethical perspective, see e.g. Wenz 1988, chapter on cost-benefit analysis.

4. In Penz 1992, I argue for an equal-sharing perspective even with respect to the land of indigenous peoples, but introduce important caveats that normally rule out the redistribution of frontier land from tribal peoples to colonizing landless peasants.

\section{References}

Bodley, John H. 1990. Victims of Progress. 3d ed. Mountain View, CA: Mayfield Publishing.

Penz, Peter. 1991. "The priority of basic needs: toward a consensus in development ethics for political engagement." In Ethical principle for Development: Needs, Capacities or Rights? edited by K. Aman, 35-73. Upper Montclair, NJ: Institute for Critical Thinking, Montclair State College.

—. 1992. "Development Refugees and Distributive Justice: Indigenous Peoples, Land, and the Developmentalist State." Public Affairs Quarterly 6, no. 1, 105-31.

-1993. "Colonization of Tribal Lands in Bangladesh and Indonesia: State Rationales, Rights to Land, and Environmental Justice." In Asia's Environmental Crisis, edited by M. C. Howard, 37-72. Boulder, CO: Westview Press.

- 1997. "International Environmental Justice: The Global Environment and Rich-Country Obligations." In Canadian Issues In Environmental Ethics, edited by A. Wellington, A. Greenbaum, and W. Cragg. Peterborough, ON: Broadview Press.

Rawls, John. 1971. A Theory Of Justice. London, UK: Oxford University Press.

Smith, David M. 1994. Geography and Social Justice. Oxford, UK: Blackwell.

Sterba, James P. 1992. Justice: Alternative Political Perspectives. $2 \mathrm{~d}$ ed. Belmont, CA: Wadsworth Publishing.

Wenz, Peter S. 1988. Environmental Justice. Albany, NY: State University of New York Press. $\square$

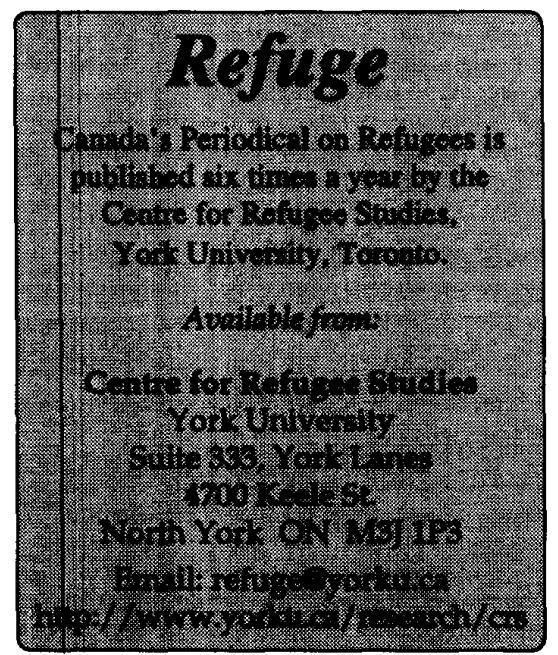




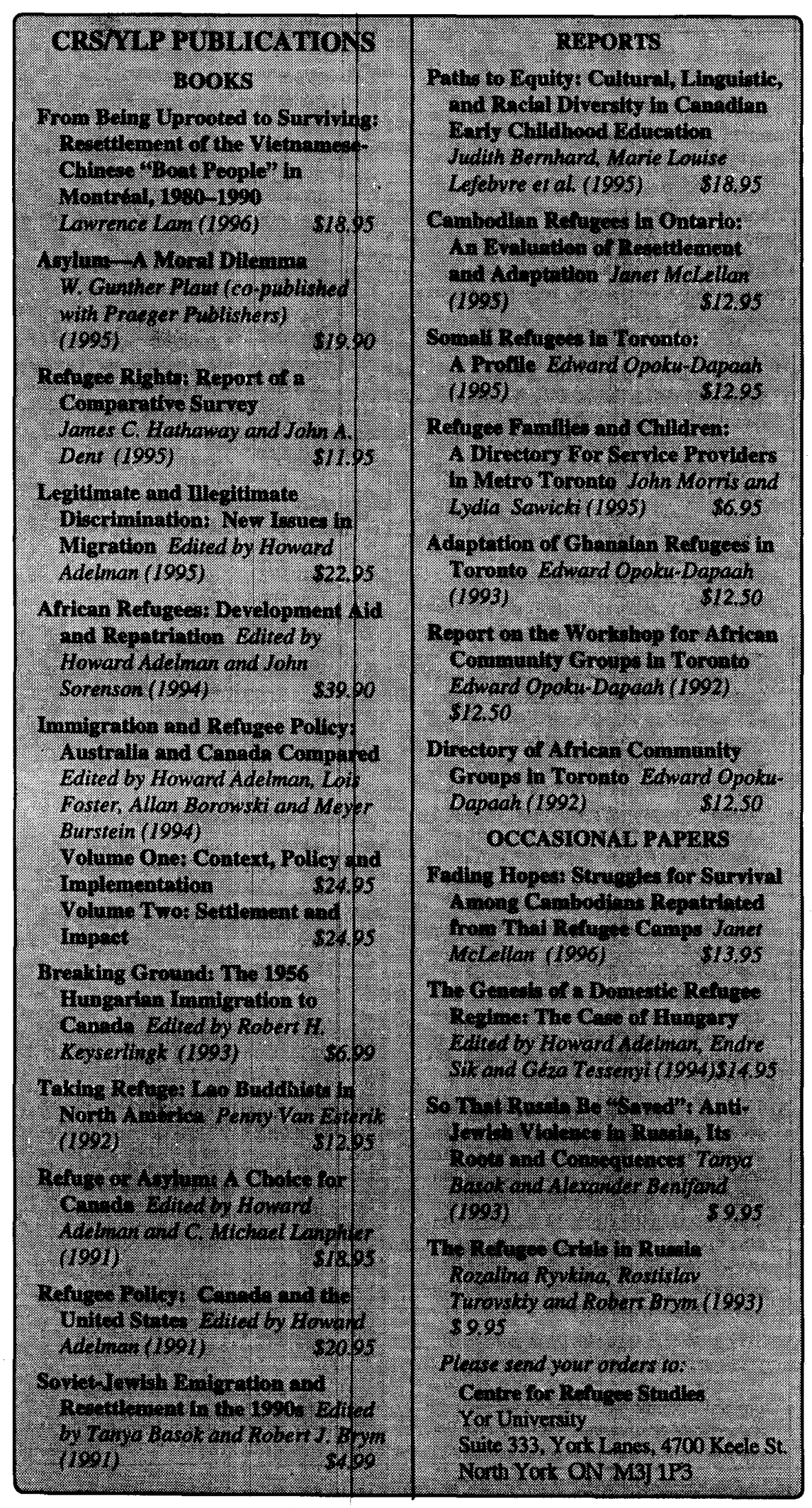

\section{Legitimate and Illegitimate Discrimination:}

\section{New Issues in Migration}

\author{
Edited by Howard Adelman \\ ISBN 1-55014-238-0. 1995. \\ 287 pp., indexed. $\$ 22.95$
}

Freedom of movement: If the members of a state are forced to flee, the legitimacy of that government is questionable. On the other hand, if members cannot or must leave, again the government is not democratically legitimate.

Immigration control: While limiting access and determining who may or may not become members of a sovereign state remains a legitimate prerogative of the state, the criteria, rules and processes for doing so must be compatible with its character as a democratic state.

Legitimate and Illegitimate Discrimination: New Issues in Migration, edited by Professor Howard Adelman, deals with the question of legitimacy with cases studies from the Developing World, Europe, Australia, the United States, and Canada.

\section{ConTRIBUTORs:}

Rainer Bauböck, Howard Adelman, Gaim Kibreab, A. Essuman-Johnson, Grant M. Farr, Lawrence Lam, Oscar Schiappa-Pietra, Tomas Hammar, Frédéric Tiberghien (in French), Lois Foster, and Arthur C. Helton.

\section{Available from:}

\section{Centre for Refugee Studies}

Tel.: (416) 736-5843

Fax: (416) 736-5837

Email: refuge@yorku.ca 


\section{From Being Uprooted to Surviving:}

Resettlement of Vietnamese-Chinese IIBoat People" in Montreal, 1980-1990

By Lawrence Lam

Toronto: York Lanes Press ISBN 1-55014-296-8

200 pages, indexed; $\$ 18.95$

The saga of the "boat people" is a dramatic story, a story of one of the largest refugee movements in recent years. Canada played a significant role in the resettlement of these refugees in bringing them to Canada where they could start anew. From Being Uprooted to Surviving by Professor Lam, is based on ethnographic data of a sample of Vietnamese-Chinese accepted for resettlement in Montreal in 1979 and 1980, who were interviewed again in 1984--85 and in 1990-91, this book providesalongitudinal account of their experience of resettlement in Canada. This experience has been marked by successive stages of their struggle to overcome structural barriers and to negotiate, a meaningful niche in Canada.

Contents: Preface, The Boat Peopie Phenomenon, ReSettlementIssues and Perspectives, The VietnameseChinese Refugees,Exo

dus and Transition, Resettlement

Process-The First Three Years, Resettlement Beyond the First Three Years, Conclusion. Available from:

Centre for Refugee Studies

York University

Suite 333, York Lanes 4700

Keele;Street

North Yark ON M3J IP3

\section{Back Issues of Refuge}

The following is a list of general and thematic issues of Refuge-Canada's periodical on refugees.

1. Environmental Refugees, Vol. 12, No.1, June 1992.

2. Discussion ofImmigration Bill C-86, Vol. 12, No.2, July/(Aug.) 1992.

3. General Issue/Refugee Sponsorship, Vol. 12, No.3, Sept. 1992.

4. Eastern European Refugees, Vol. 12, No.4, Oct. 1992.

5. The Tragedy of Somalia, Vol. 12, No.5, Nov.lDec. 1992

6. The Review of Rejected Refugee Claims in Canada, Vol. 12, No.6, Jan. 1993. 7.

Russia and Central Eurasia, Vol. 12, No.7, February 1993.

8. Africa Issue: Repatriation, Vol. 12, No.8, March 1993.

9. General Issue/Globalization, Vol. 13, No.1, Apri11993.

10. Russia and Central Eurasia, Vol. 13, No.2, May 1993.

11. Special Issue on Sri Lanka, Vol. 13, No.3, June 1993.

12. Gender Issues and Refugee Law, Vol. 13, No.4, July/Aug. 1993.

13. Southeast Asian Refugees, Vol. 13, No.5, Sept. 1993.

14. Mozambican Refugees, Vol. 13, No.6, October 1993.

15. Russia and Central Eurasia, Vol. 13, No.7, Nov.lDec. 1993.

16. General Issue/Sudan, Vol. 13, No.8, January 1994.

17. Integration of Refugees-The Canadian Experience, Vol. 13, No.9, Feb. 1994. 18.

Refugees and Peace in Central America, Vol. 13, No. 10, March 1994.

19. Horn of Africa, Vol. 14, No.1, April 1994.

20. The Russian Federation, Vol. 14, No.2, May 1994.

21. The Former Yugoslavia, Vol. 14, No.3, June/July 1994.

22. General Issue/IRB and Rebuilding Trustrramil Immigrants in Canada, Vol.

14, No.4, Aug.lSept. 1994.

23. Rwandan Crisis, Vol. 14, No.5, October 1994.

24. Refugee Resettlement in Israel, Vol. 14, No.6, Nov. 1994.

25. Refugee Women-Part 1: Issues, Vol. 14, No.7, Dec. 1994.

26. Refugee Women-Part 2: Case Studies, Vol. 14, No.8, Jan. 1995.

27. The Safe Third Country Concept, Vol. 14, No.9, February 1995.

28. Special Issue on Chechnya, Vol. 14, No. 10, March 1995.

29. Reformulation ofInternational Refugee Law, Vol. 15, No.1, 1996

30. Environment, Development and Refugees, Vol. 15, No.2, 1996.

31. International Intervention in Refugee Crises, Vol. 15, No.3, 1996.

32. Early Warning on Humanitarian Crises, Vol. 15, No.4, 1996.

33. Child Refugees, Vol. 15, No.5, 1996.

34. Global Settlement Services, Vol. 15, No.6, 1997.

35. Early Warning and Early Response, Vol. 16, No.1, May 1997.

36. Uprooting and Consequences, Vol. 16, No.2, June 1997.

Single copy: Vol 12, 13 \&14-\$6.50; Vol 15-\$10. 10 percent discount on 3-9 issues (copies); 20 percent discount on 10 issues (copies) or more. Special discounts are available for students and exclusively volunteer-run NGOs. P. O. accepted. Please send your orders to:

Centre for Refugee Studies, York University

Suite 333, York Lanes, 4700 Keele Street

North York, Ontario, M3J IP3, Canada

Fax: (416) 736-5837 Email: refuge@yorku.ca 


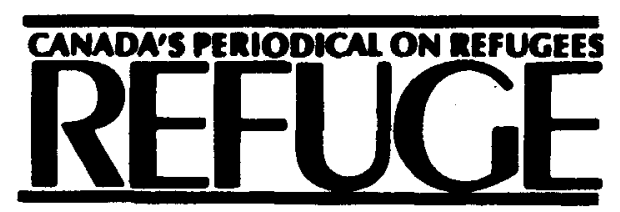

Refuge

Centre for Refugee Studies Suite 322, York Lanes

York University

4700 Keele Street, North York

Ontario, Canada M3J 1P3

Phone: (416) 736-5663

Fax: (416) 736-5837

Email: refuge yorku.ca

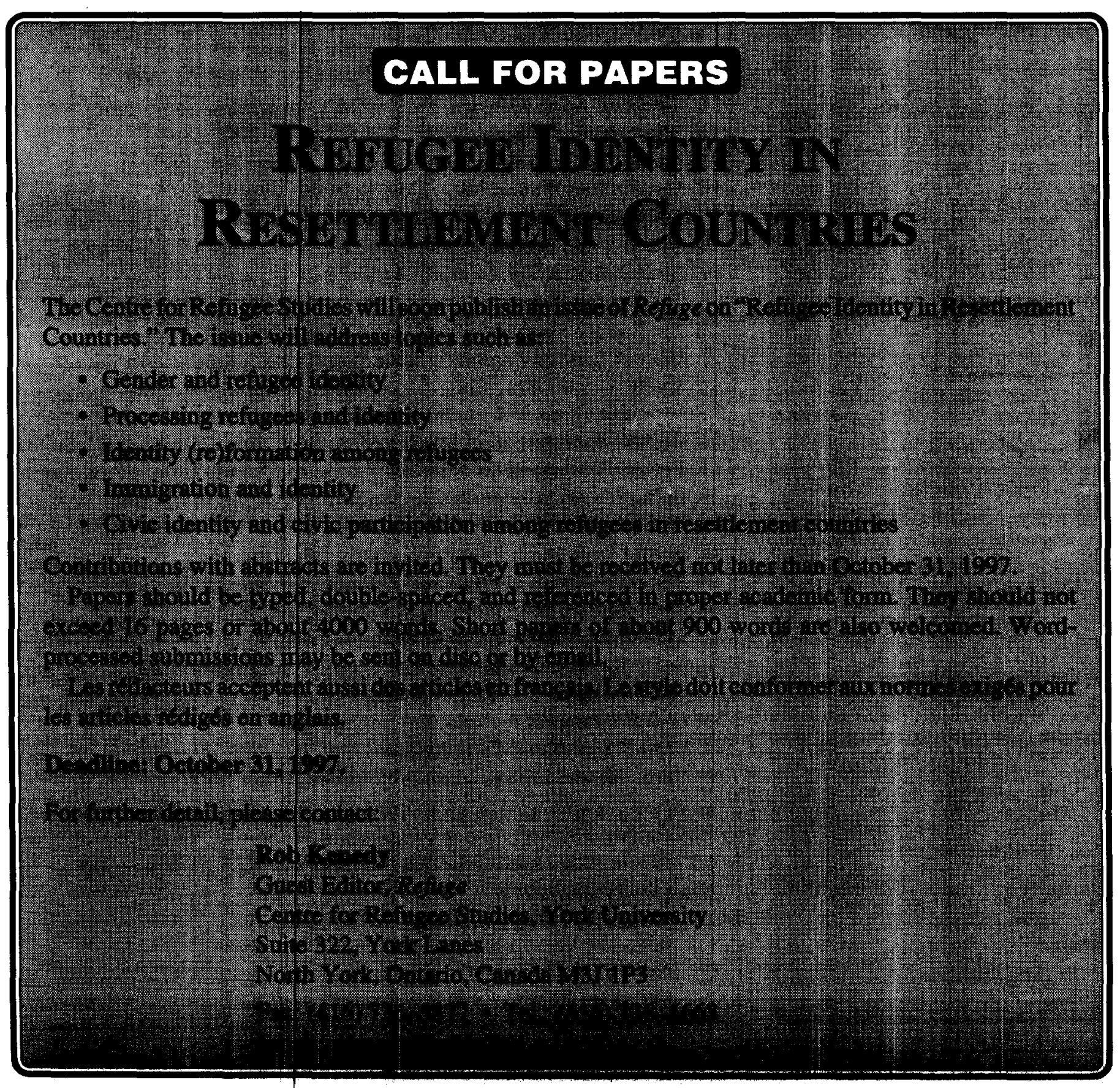

(C) Peter Penz, 1997. This open-access work is licensed under a Creative Commons Attribution-NonCommercial 4.0 International License, which permits use, reproduction and distribution in any medium for non-commercial purposes, provided the original author(s) are credited and the original publication in Refuge: Canada's Journal on Refugees is cited. 